\title{
䁇業界に望む建築材料研究者の立場から
}

\section{白山和 久}

建築に使用されている筀業製品は少なくないが，筆者 は、コンクリートの研究を主に行なっているので, 致業 界に対する要望といっても, 主にセメント関係に限られ てしまったてとをはじめにお断りしておく.

一番出現を待望している䈍業製品といえば，建築に 一 携わるものならば, まず誰でも亀裂のできないコ ンクリートやモルタルを作れるセメントをその一つにあ げるであろう。モルタルやコンクリートの莗裂はセメン トだけが原因であるとはいわないが，何といっても根本 的な原因はセメントの性質自体にある。多少でる収縮の 少ない, 変形能力の大きい, 引張強度の高いセメントを 何とかして作って戴きたいものである.

七 たいと思う.

新 しい規格によって，混合セメントの種類は増した が，現実にはどのセメントも規格値をはるが上 廻る高強度のものばかり出廻っているようである．セメ ント強度の高いととは結構だが，压縮強度を高くするた めに他の性質が犠牲になったり，それほど高強度のセメ ントは必要でない場合にも, 高強度ではあるが安くない セメントを使わざるを得ないのが現状である。フランス では強度別の等級があり，例えば普通ポルトランドセメ ントでも保証 4 週強度が $250 \sim 315 \mathrm{~kg} / \mathrm{cm}^{2}$ クラスのも のと，160 250 kg/cm² クラスのものとでは約 1 割の值 段の差がある．品質のよいものは高く，品質の劣るもの は安く売るのは当然で，わが国でもてのようなセメント の等級別が行なわれれば，需要者側も使用条件に応じて 適当な品質のセメントを適当な価格で使うことができ， 国家経済の上からも有利だと思うのだが如何なものであ ろうか.

またとくに小規模な工事の多い建築工事では，セメン 卜の素姓がわかると何かと便利なととが多い。だから， 焼成・袋詰・出荷された年月日，工場名をセメント袋な ぞに記入するとかの方法で，素姓がわかるようにして貪 いたいと思う。もしできなければ，出荷番号のようなも のでもよい.

少 々話は飛ぶけれどもコンクリートについては，ど うやって容易に不用になったコンクリート建造物

この記事は去る5月 29 日, 日本化学会講堂で開いた「新しい 建築材料」講演会における講演の要旨である. 発表の遅れたこ とを記してお詑び申上げます。

筆者湕設省建築研究所第 2 研究部
を手際よく取り壊すかという研究も今からそろそろ始め ていても早くはないと思われる，建築の方でも考えなけ ればならない問題だが，筀業の專門家ならば，また名案 もあるのではないだろうか.

近

頃の建築界の一つの方向は, 建物の軽量化と工業 生産化とを推し進めるととにある. 建物の軽量化 は建物の高層化と機能向上との両面に有利になる．そと で窵業材料もこのような流れ沿うようなものが望まれ る。例えば煉瓦やコンクリートブロックに代る気孔の多 い，軽い大型の七ラミックブロック，優秀で比較的安い 人工膨脤骨材などである.

現 在のセラミック成形品については次のような点を 改良すべきだと思う。一つは，形状・大きさの問 題である．セラ之ック成形品は一般に切断や加工が困難 であるから，製品をそのままの形で使用しなければなら ない，従って形状や大きさに一段の工夫が欲しい，寸法 については最近建築モデュールも発表されたので，てれ らも参考にされたい。瓦などももう少し緩勾配でも雨 仕舞よく苟くことができ，軽量でかつ風にも飛ばない新 しい感覚のデザインがないだろうか。 また成形品の接着 材料, たとえば左官仕上の天井やタイルの貼付・ブロッ クの目地には充分信頼できる材料がなく，構造の弱点と なるし，タイルの剥離，落下などによる事故も生じてい る.むずかしいとは思うが，優秀な接着材料の出現が待 たれる。

最後に，ガラスは建築では最も重要な窑業製品の一 つであるが，普通のガラスでは防火上の弱点にな ろ.

といって網入ガラスを使ったのでははなはだ感じの亜 くなるととが多い，高熱付えるガラスを狩洒に作るの が無理ならば，部分的に熱せら机ると直ぐ全面に亀裂が 入るものではなく，その部分だけは軟化してしまっても よいから，全面破壊に至ら妨よにはならない゙あろう か.

以上日頃見たり聞いたり感じたりした勝手な注文を並 べたてただけで申し訳ないように思うが，てれらは勿論 窯業関係だけで解決できない点も多いと思われるので， 今後は突業と建築との技術者とががよ密接に協力し て，てのような問題を解決できれば建築界にとっても真 に幸であると思う。 